\title{
ДЕНДРОФЛОРА БАЛКИ ШИРОКА (ОСТРІВ ХОРТИЦЯ)
}

Байрачні ліси Запорізької обл. відносять до байраків порожистої частини Дніпра. Вони мають важливе кліматичне та грунтозахисне значення, у них трапляються представники лісових, степових, лугових фітоценозів, часто - рідкісні й ендемічні види, а також місцева фауна. Такі заліснені балки характеризуються високою атракторною здатністю для рекреантів, діяльність яких призводить до трансформації рослинності байрачно-лісових фітоценозів. 3 огляду на це актуальною $є$ інформація про стан їх дендрофлори для створення банку даних та оперативного моніторингу. Наведено дані про видовий склад дендрофлори балки Широка, розташованої на о. Хортиця (зона рекреаційної діяльності туристів та мешканців м. Запоріжжя), де зареєстровано 54 види деревних рослин, що належать до 43 родів і 26 родин. Встановлено, що найбільшим видовим насиченням характеризується родина Rosaceae Adans. У складі дендрофлори байрачного лісу аборигенні види становлять $48,1 \%$, інтродуковані - 51,9\%. Найбільша частка участі серед інтродукованих видів належить породам північноамериканського походження (11 видів, або 39,3\% від усієї кількості інтродуцентів). Інтродуценти представлені здебільшого Amorpha fruticosa, Robinia pseudoacacia, Morus alba та Celtis occidentalis. Основними лісотвірними аборигенними породами насадження є Acer platanoides, Quercus robur, Ulmus scabra, A. tataricum. З'ясовано породний склад верхніх ярусів деревостану та підліску, що зростають на території різних морфологічних частин балки. Байрачний ліс має значний ресурсний потенціал, включаючи медоносні та вітамінні рослини. У складі насадження виявлено види з високою інвазійною здатністю (Acеr negundo, Amorpha fruticosa, Robinia pseudoacacia) та той, що визнано інвазійним у списках близьких до України територій (Parthenocissus quinquifolia).

Ключові слова: байрачний ліс; деревна рослинність; біорізноманіття; систематична структура флори.

Вступ. Байрачні ліси Запорізької обл. відносять до байраків порожистої частини Дніпра. Вони є південним форпостом цього типу рослинності (Bel'gard, 1950, 1971). Як відомо, ліси мають важливе кліматичне (Crane, 1985), грунтозахисне та агротехнічне значення. Окрім цього, байрачні ліси - це своєрідний рефугіум для фауни, в них трапляються представники лісових, степових, лугових та інших типів фітоценозів, часто - рідкісні й ендемічні види. Такі заліснені балки мають високу атракторну властивість для населення великих промислових міст і виступають ареною його рекреаційної активності. Внаслідок неконтрольованого антропогенного впливу байрачно-лісова рослинність деградує, при цьому природні фітоценози насичуються антропофітами й інвазійними видами.

Рослинний покрив байраків о. Хортиця піддається впливу рекреантів, зазнає трансформації внаслідок старіння насаджень, зміни порід тощо. 3 огляду на це, актуальною $\epsilon$ інформація про стан їх дендрофлори для створення банку даних. Це підвищить ефективність i оперативність моніторингових заходів і буде основою для розробки способів збереження фітоценозів та цінних дендрооб'єктів (Bessonova, Zaitseva \& Nemchenko,
2017).

Актуальність подібного роду досліджень очевидна 3 огляду на розроблення "Концепції збереження та сталого використання лісових генетичних ресурсів", що було представлено вперше в Україні з метою забезпечення сталого функціонування лісових екосистем, збереження потенціалу лісів для майбутніх поколінь та вдосконалення наявних законодавчих документів щодо підтримання біорізноманіття в лісах (Krynytskyi et al., 2017).

Мета дослідження - вивчення видового складу i стану дендрофлори байрачного лісу балки Широка.

Матеріал і методи дослідження. Дослідження проводили в байрачному лісі балки Широка на о. Хортиця, що входить до рекреаційної сфери м. Запоріжжя. На схилі південно-східної експозиції розташований санаторій-профілакторій титано-магнієвого комбінату (ЗТМК). Балка має 23 відроги, тому інша іï назва - Оленячий ріг.

Балка розташована в підзоні різнотравно-типчаковоковилового степу.

Дослідження проводили маршрутним методом на основі біогеоценотичного принципу (Sukachev, 1964, 1966). Зібрані рослини гербаризували за загальноп-

\section{Інформація про авторів:}

Яковлєва-Носарь Світлана Олегівна, канд. біол. наук, доцент, доцент кафедри садово-паркового господарства та генетики. Email: krokus17.zp@gmail.com

Бессонова Валентина Петрівна, д-р біол. наук, професор, завідувач кафедри садово-паркового господарства.

Email: spg.dsaeu@gmail.com

Цитування за ДСтУ: Яковлєва-Носарь С. О., Бессонова В. П. Дендрофлора балки широка (острів Хортиця) . Науковий вісник Нлту України. 2018, т. 28, № 2. С. 26-30.

Citation APA: Yakovlieva-Nosar, S. O., \& Bessonova, V. P. (2018). Dendroflora of the Shyroka Balka Ravine (Hortiza Island) . Scientific Bulletin of UNFU, 28(2), 26-30. https://doi.org/10.15421/40280203 
рийнятою методикою (Skvortsov, 1977). Видовий склад дендрофлори визначали згідно з "Визначником вищих рослин України" (Opredelytel, 1999), а також використовували довідкові видання (Zaiachuk, 2008). Картосхему території дослідження зображено на рис.

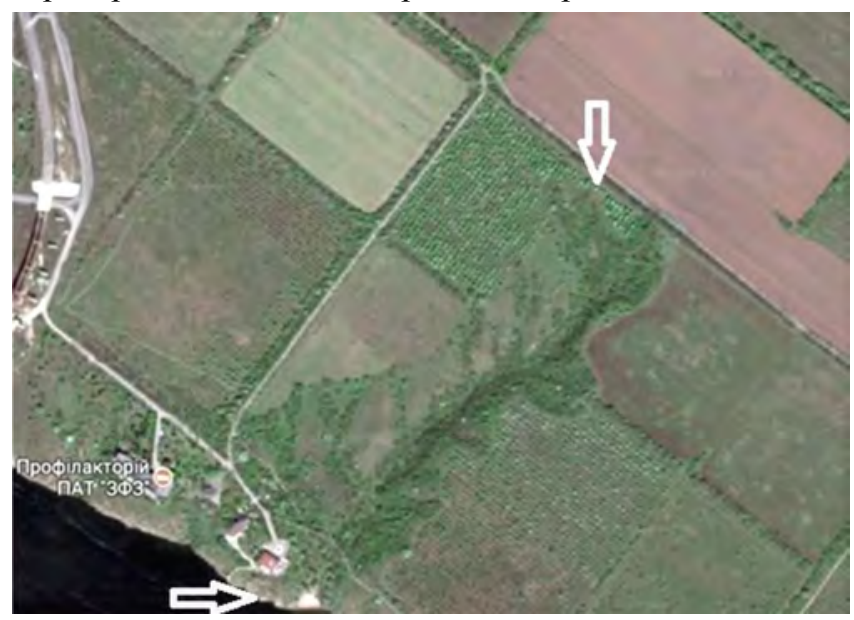

Рис. Картосхема території дослідження (https://www.google.com.ua/maps/) (координати зазначених точок $47^{\circ} 49 ' 23,1^{\prime \prime} \mathrm{N}$

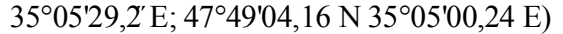

Результати дослідження та їх обговорення. На території балки Широка зростає 54 види деревних рослин, що належать до 26 родин (табл.). Відділ Pinophyta представлено 2 видами, відділ Magnoliophyta - 52 видами.

Табл. Таксономічний список дендрофлори балки Широка

\begin{tabular}{|c|c|c|}
\hline \begin{tabular}{|l|}
$№$ \\
$3 / \Pi$
\end{tabular} & Вид & Первинний ареал \\
\hline 1 & 2 & $\overline{3}$ \\
\hline \multicolumn{3}{|c|}{ PINOPHYTA } \\
\hline \multicolumn{3}{|c|}{ Cupressaceae S. F. Gray } \\
\hline 1 & $\begin{array}{l}\text { Thuja orientalis L. [Biota orienta- } \\
\text { lis (L.) Endl., Platycladus orienta- } \\
\text { lis (L.) Franco] }\end{array}$ & $\begin{array}{c}\text { Північний Китай, Ко- } \\
\text { рея, Маньчжурія, Дале- } \\
\text { кий Схід Росії }\end{array}$ \\
\hline \multicolumn{3}{|c|}{ Pinaceae Lindl. } \\
\hline 2 & Pinus silvestris L. & аб. \\
\hline \multicolumn{3}{|c|}{ MAGNOLIOPHYTA } \\
\hline \multicolumn{3}{|c|}{ Aceraceae Lindl. } \\
\hline 3 & Acer negundo L. & Північна Америка \\
\hline 4 & A. platanoides $\mathrm{L}$. & аб. \\
\hline 5 & A. tataricum L. & аб. \\
\hline 6 & A. saccharinum L. & Північна Америка \\
\hline \multicolumn{3}{|c|}{ Anacardiaceae Lindl. } \\
\hline 7 & Cotinus coggygria Scop. & аб. \\
\hline \multicolumn{3}{|c|}{ Berberidaceae Torr. et Gray } \\
\hline 8 & Berberis vulgaris L. & аб. \\
\hline \multicolumn{3}{|c|}{ Bignoniaceae Pers. } \\
\hline 9 & Catalpa bignonioides Walt. & Північна Америка \\
\hline \multicolumn{3}{|c|}{ Caprifoliaceae Vent. } \\
\hline 10 & Lonicera tatarica $\mathrm{L}$. & $\begin{array}{c}\text { європа, Східний Сибір, } \\
\text { Середня Азія }\end{array}$ \\
\hline 11 & Symphoricarpos albus (L.) Blake & Північна Америка \\
\hline \multicolumn{3}{|c|}{ Celastraceae $\mathrm{R} . \mathrm{Br}$. } \\
\hline 12 & Euonymus europaea L. & аб. \\
\hline 13 & E. verrucosa Scop. & аб. \\
\hline \multicolumn{3}{|c|}{ Elaeagnaceae Juss. } \\
\hline 14 & Elaeagnus angustifolia $\mathrm{L}$. & Середземномор'я, Азія \\
\hline \multicolumn{3}{|c|}{ Fabaceae Lindl. } \\
\hline 15 & Amorpha fruticosa $\mathrm{L}$. & Північна Америка \\
\hline 16 & Caragana arborescens Lam. & Сибір, Казахстан \\
\hline 17 & Robinia pseudoacacia L. & Північна Америка \\
\hline 18 & Gleditsia triacanthos L. & Північна Америка \\
\hline \multicolumn{3}{|c|}{ Fagaceae Dum. } \\
\hline 19 & Quercus robur $\mathrm{L}$. & $\overline{\mathrm{A \sigma}}$ \\
\hline 20 & Q. rubra Du Roi & Північна Америка \\
\hline \multicolumn{3}{|c|}{ Grossulariaceae DC. } \\
\hline
\end{tabular}

\begin{tabular}{|c|c|c|}
\hline 1 & 2 & 3 \\
\hline 21 & Ribes aureum Pursh. & Північна Америка \\
\hline \multicolumn{3}{|c|}{ Hippocastanaceae Tarr. et Gray. } \\
\hline 22 & Aesculus hippocastanum L. & $\begin{array}{c}\text { гірські ліси півдня Бал- } \\
\text { канського півострова } \\
\text { (Македонія) }\end{array}$ \\
\hline \multicolumn{3}{|c|}{ Hydrangaceae Endl. } \\
\hline 23 & Philadelphus coronarius L. & Південна Європа \\
\hline \multicolumn{3}{|c|}{ Juglandaceae A. Richard ex Kunth. } \\
\hline 24 & Juglans regia L. & Центральна Азія \\
\hline \multicolumn{3}{|c|}{ Moraceae Link } \\
\hline 25 & Morus alba L. & Східний Китай \\
\hline \multicolumn{3}{|c|}{ Oleaceae Hoffmgg. et Link } \\
\hline 26 & Fraxinus excelsior $\mathrm{L}$. & аб. \\
\hline 27 & Ligustrum vulgare L. & аб. \\
\hline 28 & Syringa vulgaris L. & Балканський півострів \\
\hline \multicolumn{3}{|c|}{ Rhamnaceae Juss. } \\
\hline 29 & Rhamnus cathartica L. & аб. \\
\hline \multicolumn{3}{|c|}{ Rosaceae Adans. } \\
\hline 30 & Amygdalis nana $\mathrm{L}$. & аб. \\
\hline 31 & Armeniaca vulgaris Lam. & $\begin{array}{c}\text { Гірські ліси Тянь-Ша- } \\
\text { ню }\end{array}$ \\
\hline 32 & Cerasus fruticosa (Pall.) G. Woron. & аб. \\
\hline 33 & $\begin{array}{c}\text { Cotoneaster melanocarpus Fisch. } \\
\text { ex Blytt }\end{array}$ & аб. \\
\hline 34 & Crataegus monogyna Jacq. & аб. \\
\hline 35 & Malus domestica Borkh. & $\begin{array}{c}\text { Південний Казахстан, } \\
\text { Киргизія (Передгір'я } \\
\text { Алатау) }\end{array}$ \\
\hline 36 & $\begin{array}{l}\text { M. sylvestris (L.) Mill. [Malus pra- } \\
\text { ecox Borkh.] }\end{array}$ & аб. \\
\hline 37 & Prunus domestica L. & Закавказзя, Мала Азія \\
\hline 38 & P. spinosa L. & аб. \\
\hline 39 & Pyrus communis L. & аб. \\
\hline 40 & Rosa canina L. & аб. \\
\hline 41 & Spiraea vanhouttei Zab. & $\begin{array}{c}\text { Культивують в Свропі, } \\
\text { Середній Азії, на Кав- } \\
\text { казі та в Північній Аме- } \\
\text { риці }\end{array}$ \\
\hline 42 & S. hypericifolia L. & аб. \\
\hline \multicolumn{3}{|c|}{ Salicaceae Mirb. } \\
\hline 43 & Populus nigra L. & аб. \\
\hline 44 & P. alba L. & аб. \\
\hline 45 & Salix babylonica L. & Китай \\
\hline \multicolumn{3}{|c|}{ Sambucaceae Link. } \\
\hline 46 & Sambucus nigra L. & аб. \\
\hline \multicolumn{3}{|c|}{ Simaroubaceae DC. } \\
\hline 47 & Ailanthus altissima Mill. & Північний Китай \\
\hline \multicolumn{3}{|c|}{ Tamaricaceae Lindl. } \\
\hline 48 & Tamarix laxa Willd. & $\begin{array}{c}\text { Південно-Східна Євро- } \\
\text { па, Кавказ, Середня } \\
\text { Азія, Іран, Монголія }\end{array}$ \\
\hline \multicolumn{3}{|c|}{ Tiliaceae Juss. } \\
\hline 49 & Tilia cordata Mill. & аб. \\
\hline \multicolumn{3}{|c|}{ Ulmaceae Mirb. } \\
\hline 50 & Celtis occidentalis L. & Північна Америка \\
\hline 51 & Ulmus laevis Pall. & аб. \\
\hline 52 & $\begin{array}{c}\text { U. pumila L. [U. pinnato-ramosa } \\
\text { Dieck. ex Koehne] }\end{array}$ & Азія \\
\hline 53 & U. scabra Mill. & аб. \\
\hline \multicolumn{3}{|c|}{ Vitaceae Lindl. } \\
\hline 54 & $\begin{array}{l}\text { Parthenocissus quinquifolia (L.) } \\
\text { Planch. }\end{array}$ & Північна Америка \\
\hline
\end{tabular}

Примітка: аб. - місцева рослина.

Найбільшою кількістю видів представлено родини: Rosaceae Adans. (13); Aceraceae Lindl., Fabaceae Lindl. i Ulmaceae Mirb. (по 4 види); Oleaceae Hoffmgg. et Link i Salicaceae Mirb. (по 3 види). Двома видами представлено родини Caprifoliaceae Vent., Celastraceae R. Br. та Fagaceae Dum., і тільки одним видом - родини Cupressaceae S. F. Gray, Pinaceae Lindl., Anacardiaceae Lindl., Berberidaceae Torr. et Gray, Bignoniaceae Pers., Elaeag- 
naceae Juss., Grossulariaceae DC., Hippocastanaceae Tarr. et Gray., Hydrangaceae Endl., Juglandaceae A. Richard ex Kunth., Moraceae Link, Rhamnaceae Juss., Sambucaceae Link., Simaroubaceae DC., Tamaricaceae Lindl., Tiliaceae Juss., Vitaceae Lindl.

Оскільки деякі види дендрофлори балки є декоративними, яких використовують для озеленення населених місць, тому присутність таких рослин на дослідженій території зумовлена їх роллю у композиційному оформленні санаторію-профілакторію. Територію цієї установи, безпосередньо з центральним тальвегом балки, з'єднують сходи, уздовж яких висаджено декоративні рослини (Thuja orientalis, Syringa vulgaris, Spiraea vanhouttei, Lonicera tatarica). У насадження центральної частини балки, яку часто відвідують рекреанти, вкраплені рослини Thuja orientalis, Acer saccharinum та Philadelphus coronaries.

Порівняння багатства дендрофлори байраку Військовий, який також належить до південного географічного варіанта, свідчить про дещо менше його видове різноманіття. На території цього байраку було виявлено 46 видів деревних рослин, що належать до 31 роду і 21 родини. При цьому частка інтродуцентів у складі дендрофлори становила 34,8 \% (Bessonova, Zaitseva \& Nemchenko, 2017).

У складі дендрофлори байрачного лісу балки Широка аборигенні види становлять 48,1 \%, тоді як інтродуковані - 51,9 \%. Найбільша частка участі з числа інтродукованих видів належить північноамериканським (11 видів, або 39,3 \% від усієї кількості екзотів).

Найпоширенішими серед інтродуцентів є Amorpha fruticosa, Robinia pseudoacacia, Morus alba та Celtis occidentalis.

Основними лісовими породами природних фітоценозів дослідженого байрачного лісу є Acer platanoides, Quercus robur, Ulmus scabra, A. tataricum. У складі деревостану присутня Robinia pseudoacacia, що мігрувала у фітоценоз з оточуючих балку захисних насаджень, до складу яких входить також Gleditsia triacanthos. Ïї одиничні особини також поширились у насадження байраку. Переважаюча частина видів деревостану байрачного лісу $є$ супутніми. Їх кількісна участь істотно відрізняється. Позаярусна деревна рослинність представлена одним видом (Parthenocissus quinquifolia).

3 позиції розподілу видів дендрофлори за життєвими формами, частка власне дерев становить 56,6 \%, чагарників - 41,5 \%, ліан - 1,9 \% від загальної кількості видів.

Локалізацію дерев і чагарників у байрачному лісі визначають лісорослинними умовами схилів різних експозицій і тальвегу балки. Так, деревостан насадження схилу південно-східної експозиції здебільшого представлено Acer platanoides та A. tataricum. Присутні поодинокі генеративні екземпляри Robinia pseudoacacia, Ulmus scabra, Pyrus communis, Morus nigra. Відзначено природне поновлення Acer platanoides, A.tataricum, Celtis occidentalis, Robinia pseudoacacia. Підлісок цього фітоценозу сформований чагарниками Ligustrum vulgare, Crataegus monogyna, Euonymus europaea. У складі підліску зрідка трапляється Berberis vulgaris. Узлісся насадження формують рослини Amygdalis nana.

У тальвегу центральної частини балки видовий склад деревостану дещо відрізняється. Тут переважають такі види, як Ulmus scabra, U. pumila, Quercus robur. У підліску домінує Sambucus nigra. Варто зазначи- ти також наявність дерев Robinia pseudoacacia, iï сухостійних екземплярів та особин Ulmus scabra, U. pumila i Acer platanoides зі слідами рубок стовбурів.

У тальвегу і гирлі центральної частині балки спостерігаються ознаки активної антропогенної діяльності: кострища, сліди механічної дії на деревні рослини, спорадичні ділянки розпушеного грунту. Саме на таких ділянках трапляється самосів Quercus robur, а також окремі екземпляри підросту Aesculus hippocastanum.

У гирлі балки Широка влаштовано піщаний пляж для відпочивальників санаторію-профілакторію і рекреантів. У безпосередній близькості до води зростають генеративні рослини Populus nigra, що активно розмножуються вегетативним шляхом, а також рослини Amorpha fruticosa і Fraxinus excelsior; на деякій відстані від річки - U. laevis і підріст Gleditsia triacanthos. На гранітних відслоненнях, що межують з остепненими ділянками, трапляється Cotoneaster melanocarpus, а узлісся в цій частині балки формують зарості Spiraea hypericifolia - вид, що знаходиться в загасаючій частині свого ареалу існування.

На схилах північно-західної експозиції центральної частини балки превалюють Quercus robur та його супутні породи (Acer platanoides i A.tataricum). Разом із тим, у цих природних фітоценозах відзначається присутність генеративних екземплярів, підросту і самосіву Robinia pseudoacacia. У цьому насадженні зростає доволі багато особин Celtis occidentalis різних вікових станів. Підлісок утворюють Sambucus nigra, Crataegus monogyna i, в меншому ступені, - Cotinus coggygria. Тут же має місце штучне групове насадження Symphoricarpos albus.

У відрогах балки основною лісовою породою $є$ Q. robur 3 різними супутніми породами. На деяких ділянках деревостану переважає U. scabra.

Біля відрогів балки Широка, які розташовані 3 південно-східної сторони відносно центрального тальвегу, зростають насадження Juglans regia. Тому одиничні екземпляри цієї породи відзначаються і у фітоценозах байрачного лісу. Неподалік від цих ділянок балки також знаходиться досить старий плодовий сад.

Деякі з відрогів балки, що межують зі сільськогосподарськими угіддями, протягом 15-річного вивчення балки, з різних причин, неодноразово зазнавали дії вогню. Зокрема страждали дорослі дерева і природне поновлення Quercus robur.

У наших публікаціях вже висвітлювали стан популяцій Quercus robur i Acer platanoides балки Широка за умов рекреаційного навантаження (Tetelbaum, Bessonova \& Yakovlieva-Nosar', 2005; Yakovlieva-Nosar', 2007 a, 2007 b), а також аналізували стан степової рослинності цієї балки (Yakovlieva-Nosar', 2009; Bessonova, Zaitseva \& Yakovlieva-Nosar', 2014).

Значною кількістю екземплярів у деревостані балки представлені Acer platanoides, A. tataricum, Quercus robur, Ulmus scabra, Morus alba, Robinia pseudoacacia. У підліску численні такі види, як: Sambucus nigra, Ligustrum vulgare, Crataegus monogyna. Зазначені породи досить інтенсивно поновлюються. Місцями спостерігаємо природне поновлення Pyrus communis, Ulmus pumila, Celtis occidentalis, Acer negundo. Відносно невеликою $є$ чисельність генеративних екземплярів Celtis occidentalis i Ulmus laevis. Виявлено поодинокі екземпляри Tilia cordata, Fraxinus excelsior, Juglans regia, Aesculus 
hippocastanum, Caragana arborescens, Gleditsia triacanthos, Ailanthus altissima, Populus nigra, P. alba.

Значна частина байрачно-лісових видів досліджених фітоценозів має господарську цінність. До вітамінних рослин дендрофлори балки Широка належать Berberis vulgaris, Juglans regia, Morus alba, Rosa canina, Malus sylvestris, до медоносних - Acer tataricum, A. platanoides, Robinia pseudoacacia, Quercus robur, Lonicera tatarica, Caragana arborescens, Amorpha fruticosa, Crataegus monogyna, Malus domestica, Prunus spinosa, Pyrus communis, Tilia cordata, Cerasus fruticosa, a Cotinus coggygria є джерелом танідної сировини.

Варто зазначити, що дослідженнями (Samsonova, 2015) встановлено найкращий біоресурсний потенціал із медозбору району з великою кількістю заліснених ярів і байраків.

Згідно 3 Конвенцією 3 біологічного різноманіття (Convention on Biological Diversity, CBV, 1992; Konventsiia, 2002), інвазії неаборигенних видів оцінюють як другу за значенням (після безпосереднього знищення місць існування) загрозу для біорізноманіття світу. У складі насаджень балки Широка відзначено наявність інвазійних чужорідних рослин, що внесено до "чорного списку" Свропи (Acer negundo, Amorpha fruticosa, Robinia pseudoacacia), а також виду, який визнано інвазійним у списках близьких до України територій (Parthenocissus quinquifolia). Як відзначають деякі автори (Abduloieva, Shevchyk \& Karpenko, 2009; Abduloieva \& Karpenko, 2013), зазначені види ще називають трансформерами, оскільки вони проявляють широку екологічну амплітуду і значний адаптаційний потенціал під час розширення екологічного ареалу. За характером впливу на екосистеми, згідно з Abduloieva, Shevchyk \& Karpenko, 2009, зазначені вище інвазійні рослини-трансформери поділять на такі групи: гіперспоживачі ресурсів (Parthenocissus quinquifolia); донори обмежених ресурсів, зокрема азоту (Robinia pseudoacacia, Amorpha fruticosa); закріплювачі пісків та берегів (Amorpha fruti$\cos a)$; ті, що сприяють інтенсивному накопиченню підстилки та опаду (Acer negundo).

Чисельність небезпечних інвазійних видів Acer negundo i Ailanthus altissima у складі деревостану балки Широка є поки що незначною. Особини Robinia pseudoacacia розташовані мозаїчно по всій території балки. Рослини Parthenocissus quinquifolia трапляються переважно у районі верхівки балки та у центральній іiі частині поблизу схилу південно-східної експозиції. Amorpha fruticosa локалізується у гирлі балки, на березі р. Дніпро.

\section{Висновки}

1. Дендрофлора балки Широка представлена 54 видами деревних рослин, що належать до 43 родів і 26 родин. Аборигенні види становлять $48,1 \%$, а інтродуковані 51,9 \% від загальної кількості видів фітоценозу.

2. Основними лісовими породами природних фітоценозів дослідженого байрачного лісу є Acer platanoides, Quercus robur, Ulmus scabra, A. tataricum. Серед інтродуцентів найбільш поширеними є Amorpha fruticosa, Robinia pseudoacacia, Morus alba та Celtis occidentalis.

3. Серед деревних порід насадження балки виявлено медоносні (13 видів) і вітамінні (5 видів) рослини.

4. У складі фітоценозів байраку зареєстровано види з високою інвазійною здатністю (Acer negundo, Amorpha fruticosa, Robinia pseudoacacia) та той, що визнано ін- вазійним (Parthenocissus quinquifolia), хоча чисельність їх ще не велика, представники обох категорій можуть бути загрозою для біологічного різноманіття байрачного лісу.

Перспективним є докладне вивчення природного поновлення аборигенних та інтродукованих деревних порід, що входять до складу насадження байрачного лісу, а також проведення подальшого моніторингу за поширенням на території балки інвазійних видів.

\section{Перелік використаних джерел}

Abduloieva, O. S., Shevchyk, V. L., \& Karpenko, N. I. (2009). Invaziini chuzhynni vydy vyshchykh roslyn u roslynnykh uhrupovanniakh Kanivskoho pryrodnoho zapovidnyka. Zapovidna sprava $v U k-$ raini, 15(2), 31-36. [in Ukrainian].

Abduloieva, O., \& Karpenko, N. (2013). Pokaznyky invaziinoho potentsialu chuzhynnykh roslyn yak osnova protsedury otsinky ryzyku. Visnyk Kyivskoho natsionalnoho universytetu im. T. Shevchenka, 16, 51-53. [in Ukrainian].

Bel'gard, A. L. (1950). Lesnaya rastitel'nost' yugo-vostoka USSR. Kyiv: Izd-vo KGU. 263 p. [in Russian].

Bel'gard, A. L. (1971). Stepnoe lesovedenie. Moscow: Izd-vo Lesn. prom-st'. 336 p. [in Russian].

Bessonova, V. P., Zaitseva, I. A., \& Nemchenko, M. V. (2017). Dendroflora urochishcha "Voiskovaya balka" (Dnepropetrovskaya oblast'). Fitoraznoobrazie Vostochnoi Evropy, XI(2), 70-77. [in Russian].

Bessonova, V. P., Zaitseva, I. A., \& Yakovlieva-Nosar', S. O. (2014). Vplyv rekreatsii na stan stepovykh dilianok balky Shyrokoi o. Khortytsia. Scientific Bulletin of UNFU, 24(9), 109-114. [in Ukrainian].

Crane, A. J. (1985). Possible effect of rising $\mathrm{CO}_{2}$ on climate. Plant cell environment, 8(6), 371-379. https://doi.org/10.1111/j.1365- 3040.1985.tb01672.x

Konventsiia. (2002). Konventsiia pro okhoronu bioriznomanittia (m. Rio-de-Zhaneiro, 5 chervnia 1992 roku) Zbirnyk mizhnarodno-pravovykh aktiv u sferi okhorony dovkillia, (pp. 329-342). (2nd ed.). Lviv: Norma. [in Ukrainian].

Krynytskyi, H. T., Hayda, Yu. I., Yatsyk, R. M., Parpan, V. I., \& Los, S. A. (2017). Concept for the conservation and sustainable use of forest genetic resources in Ukraine. Scientific Bulletin of UNFU, 27(8), 37-44. https://doi.org/10.15421/40270805

Opredelitel'. (1999). Opredelitel' vysshikh rastenii Ukrainy. Kyiv: Fitosotsiotsentr. 548 p. [in Russian].

Samsonova, I. D. (2015). Otsenka medonosnykh resursov na zemlyakh lesnogo fonda Rostovskoi oblasti. Lesnoi zhurnal, 1, 45-53. [in Russian]. https://doi.org/10.17238/issn0536-1036.2015.1.45

Skvortsov, A. K. (1977). Gerbarii. Posobie po metodike i tekhnike. Moscow: Nauka. 199 p. [in Russian].

Sukachev, V. N. (1964). Osnovnye ponyatiya lesnoi biogeotsenologii. Osnovy lesnoi biogeotsenologii, (pp. 5-49). Moscow: Nauka. [in Russian].

Sukachev, V. N. (1966). Osnovnye ponyatiya o biogeotsenozakh i obshchee napravlenie ikh izucheniya. Programma $i$ metodika biogeotsenoticheskikh issledovanii, (pp. 12-50). Moscow: Nauka. [in Russian].

Tetelbaum, Yu. V., Bessonova, V. P., \& Yakovlieva-Nosar', S. O. (2005). Stan tsenopopuliatsii Quercus robur L. bairakiv porozhystoi chastyny Dnipra za umov rekreatsii. Visnyk Zaporizkoho natsionalnoho universytetu. Seriia: Biolohichni nauky, 1, 180-187. Zaporizhzhia: ZNU. [in Ukrainian].

Yakovlieva-Nosar', S. O. (2007 b). Stan tsenopopuliatsii Quercus robur L. balky Shyrokoi za umov rekreatsiinoho navantazhennia. Pytannia bioindykatsii ta ekolohii. Period. nauk. vyd., 12(1), 10-24. Zaporizhzhia: ZNU. [in Ukrainian].

Yakovlieva-Nosar', S. O. (2007 a). Stan tsenopopuliatsii Acer platanoides L. balky Shyrokoi za umov rekreatsiinoho navantazhennia. Visnyk Donetskoho universytetu. Ser. A.: Pryrodnychi nauky, 2, 286-291. [in Ukrainian]. 
Yakovlieva-Nosar', S. O. (2009). Florystychna struktura trav'ianoi roslynnosti balky Shyrokoi o. Khortytsia. Pytannia bioindykatsii ta ekolohii. Period. nauk. vyd., 14(2), 112-121. Zaporizhzhia: ZNU. [in Ukrainian].
Zaiachuk, V. Ya. (2008). Dendrolohiia. Lviv: Apriori. 656 p. [in Ukrainian].

С. О. Яковлева-Носарь ${ }^{1}$ В. П. Бессонова ${ }^{2}$

${ }^{1}$ Запорожский национальный университет, г. Запорожье, Украина 2 Днепропетровский государственный аграрно-экономический университет, г. Днепр, Украина

\section{ДЕНДРОФЛОРА БАЛКИ ШИРОКАЯ (ОСТРОВ ХОРТИЦА)}

Байрачные леса Запорожской обл. относят к байракам порожистой части Днепра. Они имеют важное климатическое и почвозащитное значение, в них концентрируются представители лесных, степных, луговых фитоценозов, часто - редкие и эндемичные виды, а также местная фауна. Такие лесистые балки характеризуются высокой аттракторной способностью для рекреантов, деятельность которых приводит к трансформации растительности байрачнолесных фитоценозов. В связи с этим актуальной является информация о состоянии их дендрофлоры для создания банка данных и оперативного мониторинга. Приведены данные о видовом составе дендрофлоры балки Широкая, расположенной на о. Хортица (зона рекреационной деятельности туристов и жителей г. Запорожье), где зарегистрировано 54 вида древесных растений, относящихся к 43 родам и 26 семействам. Установлено, что наибольшим видовым насыщением характеризуется семейство Rosaceae Adans. B coctaве дендрофлоры байрачного леса аборигенные виды составляют 48,1 \%, интродуцированные - 51,9\%. Наибольшая доля участия среди интродуцированных видов принадлежит породам североамериканского происхождения (11 видов или 39,3 \% от всего количества интродуцентов). Интродуценты представлены, в основном, Amorpha fruticosa, Robinia pseudoacacia, Morus alba и Celtis occidentalis. Основными лесообразующими аборигенными породами насаждения являются Acer platanoides, Quercus robur, Ulmus scabra, A. tataricum. Установлен породный состав верхних ярусов древостоя и подлеска, произрастающих на территории различных морфологических частей балки. Байрачный лес имеет значительный ресурсный потенциал, включая медоносные и витаминные растения. В составе насаждения обнаружены виды с высокой инвазионной способностью (Acer negundo, Amorpha fruticosa, Robinia pseudoacacia) и признанный инвазионным в списках близких к Украине территорий (Parthenocussus quinquifolia).

Ключевые слова: байрачный лес; древесная растительность; биоразнообразие; систематическая структура флоры.

S. O. Yakovlieva-Nosar'1, V. P. Bessonova ${ }^{2}$

${ }^{1}$ Zaporizhzhia National University, Zaporizhzhya, Ukraine

${ }^{2}$ Dnipropetrovsk State Agrarian and Economic University, Dnipro, Ukraine

\section{DENDROFLORA OF THE SHYROKA BALKA RAVINE (HORTIZA ISLAND)}

Ravine forests are samples of intrazonal vegetation where numerous representatives of the fauna live, as well as plants of forest, steppe, meadow and other types of phytocoenosis, many of which are rare and endemic species. Consequently, the study of the taxonomic structure of their flora and the impact of recreational activities on the biodiversity of these natural forests is relevant. The route method based on the biogeocenotical principle for the defining of the species composition of the dendroflora represents the research technique. The research provides data on the species composition of the dendroflora of ravine Shyroka ravine, Khortytsya (recreational area of tourists and residents of Zaporizhzhia), where 54 species of woody plants belonging to 43 genera and 26 families grow. As a result, the study reviled that the Rosaceae Adans family is characterized by the highest species diversity. In the composition of the dendroflora of the birch forest, $48.1 \%$ are native species, $51.9 \%$ are introduced. The largest share of the introduced species belongs to the species of North American origin (11 species, or $39.3 \%$ of the total number of alien species). Amorpha fruticosa, Robinia pseudoacacia, Morus alba and Celtis occidentalis represent the introductants. The main forest-forming aboriginal species of the plantation are Acer platanoides, Quercusrobur, Ulmusscabra, A. tataricum. The study demonstrates the pedigree composition of the overstorey and undergrowth on the territory of various morphological parts of the ravine. Ravine forest has a significant resource potential, including honey and vitamin plants. Species with high invasive capacity (Acer negundo, Amorpha fruticosa, Robinia pseudoacacia) and those recognized as invasive (Parthenocissus quinquifolia) occur in the plantation. Consequently, the directions for future research is a detailed study of the natural renewal of native and introduced tree species, which are part of the plantation of the ravine forest, as well as further monitoring of the distribution of invasive species on the territory of the ravine.

Keywords: ravine forest; arboreal vegetation; biodiversity; systematic structure of flora. 